This is a self-archived - parallel published version of this article in the publication archive of the University of Vaasa. It might differ from the original.

\title{
Repatriation of international dual-career couples
}

Author(s): Kierner, Agnieszka; Suutari, Vesa

Title: $\quad$ Repatriation of international dual-career couples

Year: $\quad 2017$

Version: Accepted manuscript

Copyright (C)2017 Wiley Periodicals, Inc. This is the pre-peer reviewed version of the following article: Repatriation of international dual-career couples, which has been published in final form at https://doi.org/ 10.1002/tie.21947. This article may be used for non-commercial purposes in accordance with Wiley Terms and Conditions for Use of Self-Archived Versions.

\section{Please cite the original version:}

Kierner, A., \& Suutari, V., (2018). Repatriation of international dual-career couples. Thunderbird international business review 60(6), 885-895. https://doi.org/ 10.1002/tie.21947 


\title{
Repatriation of international Dual-Career Couples
}

\author{
Kierner, A. \& V. Suutari
}

\section{Thunderbird International Business Review}

\section{Executive summary}

Combining the realities of dual-career couples (DCCs) and the requirements of international careers can be difficult. In order to improve the understanding of the repatriation experiences of international DCCs, we conducted interviews with both partners in 14 DCCs. Contrary to expectations, the majority of the interviewed couples reported very successful repatriation experiences and only a few adjustment challenges were raised. The interviews address the factors explaining such repatriation adjustment issues, and also elicit four key factors (active self-management of the expatriation process, earlier experience of expatriation and repatriation, the successful integration of work life and family life, and the realization of dual-career interests upon repatriation) connected with successful repatriation adjustment experiences.

Keywords: Expatriation; Repatriation; Dual-Career Couples; Adjustment 


\section{Introduction}

It is argued that dual-career couples (DCCs), which it is suggested have made up around a quarter $(25 \%)$ of the expatriate population over the last decade (Brookfield, 2016), pose a challenge for international companies that must maintain an internationally mobile workforce (Ravasi et al., 2013; Selmer \& Leung, 2003; Shaffer et al., 2012). The limited research evidence on the experiences of such international couples has prompted frequent calls for further research (Känsälä et al., 2015; Lauring \& Selmer, 2010; Harvey et al., 2009; Huffman \& Frevert 2013; Mäkelä et al., 2011; Selmer \& Leung, 2003).

Gradually, more evidence has emerged on the experiences of DCCs during an international assignment. The associated research has addressed issues such as the willingness to leave for an assignment (Selmer \& Leung 2003), partner career experiences abroad (McNulty and Moeller, in press), partner roles (Mäkelä et al., 2011), dual-career support practices (Harvey et al., 2010; Riusala \& Suutari, 2000), cross-cultural adjustment (Ravasi et al, 2013) and career coordination strategies of the couples (Känsälä et al., 2015). However, no research on the repatriation of DCCs was found, despite the increasing body of studies focused on repatriation generally (see e.g., Szkudlarek, 2010). Overall, the repatriation stage of assignments is still an area in which there are considerable research gaps (Howe-Walsh \& Torka, 2017; Breitenmoser \& Bader 2016; Greer \& Stiles, 2016; Szkudlarek \& Sumpter, 2015), and the existing research has been predominantly focused on repatriates from North America and the UK (Sanchez-Vidal et al., 2007).

Although there is a lack of empirical research focusing on repatriation among DCCs, it has been suggested that DCCs may struggle even more with repatriation challenges than couples in which only one partner is career oriented (Haslberger et al., 2012; Linehan \& Scullion, 2002; Kierner, 2015). This is an important finding because repatriation is a challenging experience for any couple (Kraimer et al., 2012; Haslberger et al., 2012, Storti, 2003, Mäkelä \& Suutari, 2013). The need to coordinate two careers (Baird \& Reeves, 2011; Känsälä et al., 2015) and achieve a reasonable balance between work and personal life adds a new level of complexity.

The partners of expatriates face career-related challenges when they leave their job and career at home. It can be difficult finding relevant employment abroad (Yvonne and Moeller, in press), either because work permits are restricted or because of the absence of suitable opportunities in the host country. During the repatriation stage, the career issues of the partners are again among the main concerns of expatriates (Riusala \& Suutari, 2000). The negative experiences 
of the partner may have spillover effects on the expatriate, and may lead to dissatisfaction or even to a premature return to the home country (Andreason, 2008). At the same time, the partner can be an important source of support for the expatriate during the whole expatriation process (Lauring \& Selmer 2010; Haslberger \& Brewster, 2008). While it has been suggested that international DCCs would clearly benefit from organizational support practices tailored to their specific needs (Handler \& Lane, 1997), such support is seldom offered (Riusala \& Suutari, 2000; McNulty \& Moeller, in press). Couples thus typically have to deal with the problems related to adjusting to their changed situation on their own.

Against this background, the aim of this article is to increase our understanding of the repatriation adjustment experiences of international dual-career couples. As prior research has suggested, the present study involved the perspectives of both partners-expatriate and partner-to understand the different perspectives on the DCC's experience (Rusconi et al. 2013; Känsälä et al., 2015; Harvey, 1998). The findings show that the vast majority of the respondents, both expatriates and their partners, reported a successful and smooth repatriation adjustment. Therefore, building on the positive side of expatriation experiences (e.g., Mäkelä \& Suutari, 2013; Breitenmoser \& Bader, 2016; Suutari et al., 2017) we analyze both the adjustment problems of the couples, typical in repatriation adjustment research, and the findings on the factors connected with positive experiences.

\section{International Dual-Career Couples}

Rapoport and Rapoport (1971) introduced the term dual-career couple and defined it as, "a couple where both partners pursue careers." Literature has since explored various characteristics of dual-career couples looking at their engagement in continual professional employment (Bradbury, 1994), psychological commitment to their work (Harvey, 1997), and the investments the couple make in their careers as those offer the main source of fulfilment (Bird \& Schnurman-Crook, 2005). The first discussions on dual-career couples in the expatriation context appeared in the 1990s. The research at that time adopted the term dualcareer couple, standardizing the definition to those duos in which, "both partners are employed and psychologically committed to their work" (Harvey, 1997). Such an approach to DCCs has been widely used in subsequent research in the international career context (e.g., Känsälä et al., 2015; Vance \& McNulty, 2014; McNulty \& Moeller, in press). 
Being a dual-career expatriate couple does not necessarily imply that both partners will work during an international relocation (McNulty \& Moeller, in press): for the partner who is not on assignment, the options for finding a job may be limited in the host country, indeed there may even be legal constraints on having a job as a foreigner. This leads to a situation where the trailing partners may have to interrupt their career, or where paid employment is available, might end up taking a job that does not further that career (Vance \& McNulty, 2014). On the other hand, some international DCCs succeed in finding relevant career options for both partners abroad (Vance \& McNulty, 2014). Alternatively, some couples resolve the situation by living apart during the assignment so that both partners can continue their careers. Even in such circumstances, such couples are still defined as DCCs due to their long-term career orientation. We next discuss the repatriation of such couples.

\section{The repatriation adjustment of international DCCs}

Adjustment is about the person-environment relationship (Haslberger, et al., 2013) and has both an external (demands) and an internal (needs) element (Haslberger et al., 2014). Adequacy standards for the external requirements are set by the environment (Takeuchi (2010) has emphasized the importance of a variety of stakeholders), whereas internal adequacy standards are set by the individual, that is, the expatriate. Of course, these mutual needs and demands are interdependent (Brammer \& Abrego, 1981). Some of the earliest work on expatriate adjustment defined three aspects of adjustment: general adjustment, work adjustment, and interaction adjustment (Black \& Stephens, 1989); although the precise boundaries between them are not clear, perhaps largely because the model is based around an easily replicable 14-question instrument that has been much copied (Hechanova et al., 2003). This approach has also been used for repatriation research (Black et al.,1992). There is increasing evidence demonstrating the difficulty of repatriation adjustment and suggesting that the majority of repatriates are dissatisfied with the repatriation process and experience problems (Tahir \& Azhar, 2013; Chi \& Chen, 2007; Sanchez-Vidal et al., 2008, Gregersen \& Black, 1999; Suutari \& Välimaa, 2002).

It has also been recognized that the adjustment of the partner and the repatriate are significantly related to each other, since deficiencies in the adjustment of one family member affect the adjustment of the other members of the family unit (Andreason, 2008; Haslberger \& Brewster, 2008). The family conflicts can easily spill over into the work domain (Van Steenbergen et al., 
2007). According to MacDonald and Arthur (2005) both research and practice typically underestimate the importance of the partner and other family members in the adjustment to repatriation of the expatriate. For the adjustment of DCCs to be successful, it is important that both partners achieve a state of psychological comfort (Harvey, 1998).

Perhaps the most commonly discussed factors behind repatriation adjustment problems occur at work and include the underutilization of the international knowledge of the expatriate, and the resulting perceived underemployment (Kraimer et al., 2012). Expatriates come back confident in their acquired skills and with equally high expectations of how their knowledge will be utilized (Sanchez-Vidal et al., 2008). Expatriates typically have greater job responsibility and autonomy while abroad than they did previously in their organization's home country, and the (downward) status shift may create feelings of disappointment (Suutari \& Brewster, 2003). Repatriates also often face a lack of role clarity or even role conflict after repatriation (Black et al., 1992; Suutari \& Välimaa, 2002), if indeed they have a defined job to go to and are not put on to some kind of project work to fill the time before a job appropriate to their skillset can be found for them. Few repatriates receive organizational support (Black et al., 1992; Handler \& Lane, 1997; Riusala \& Suutari 2000; McNulty \& Moeller in press).

Repatriation can also be challenging for the partners in DCCs. They may be without a repatriation agreement, even if the expatriate has one, and so may need to look for a new job, perhaps having been out of the job market for some years. The partners may feel increased peer and family pressure to find employment, and failure to do so may lead to a loss of identity and self-esteem (Storti, 2003). It is therefore unsurprising that among DCCs, the job arrangements of the partner are among the main concerns of repatriating couples (Riusala \& Suutari 2000). Some expatriates may have been able to keep their jobs at home and thus be able to return to their old job. Partners may also be more realistic in their work and career expectations than expatriates with high expectations, which in turn may support their repatriation adjustment. However, there is no empirical research in these areas to support these suggestions.

There may also be issues related to re-entry to the social side of life at home because of the shift of identity caused by the experience of expatriation (Black et al., 1992). Expatriates may be surprised to experience some degree of culture shock during repatriation, and the problem is often greater for the family than for the repatriate. Multiple studies report that the more expatriates depart emotionally from home country values, the greater the culture shock and repatriation adjustment challenges (Sussman, 2002; Suutari \& Välimaa, 2002; Kraimer et al., 
2012). Interestingly, partners and self-initiated expatriates have been reported to be more exposed to the risk of remote culture influence compared to the expatriate who is more engaged in the organization culture and spends more time with other expatriates (Haslberger et al., 2012). Adjustment challenges often relate to rebuilding social connections after a period of several years abroad.

Of course, there are also many practical arrangements for the couple to deal with (Storti, 2003; Mäkelä \& Suutari, 2013). Repatriation also typically leads to the loss of additional benefits and allowances, and thus overall to a substantial reduction in income (Bonache, 2005). The expatriate may have been living in company-provided premium housing supported by a range of affordable services (like domestic cleaners and other support staff). This loss of additional support may be especially painful to dual-career families, who must split their time between family duties and the careers of both partners (Haslberger et al., 2012). When the career of the partner was on hold, the couple may also have benefited from the fact that the other partner stayed at home with the children, contributing significantly to the couple's overall work-life balance (Mäkelä \& Suutari, 2013). In the repatriation stage, however, work-life balance can again become a far more challenging issue.

The heightened stress experienced by dual-career couples during the assignment cycle means that the support of a partner becomes even more important (Lauring \& Selmer 2010; Harvey, 1998). Such support may take many forms because expatriates report that their partners have diverse roles (Mäkelä et al, 2011); those roles are often reformulated while on assignment in the new foreign environment, and expatriate couples go through a transition phase, especially when their move means the work of the partner is disrupted. Conversely, a lack of partner support, which can stem from dissatisfaction with the changed employment status of a partner in a dual-career couple, may be a source of conflict (Tharenou, 2008). When addressing repatriating, the couple again needs to renegotiate their roles in the family when both partners wish to continue their careers.

Summing up so far, the repatriation of dual-career couples is a significant and increasingly common phenomenon, but at the same time is clearly an under-researched area. The existing literature on repatriation of expatriates and their partners' reports significant challenges and the specific situation of DCCs is expected to further heighten the adjustment challenges experienced in repatriation. After presenting the methods of the study, we report new findings on the repatriation experiences of such international DCCs. 


\section{Methodology}

For this exploratory study, a qualitative research design was adopted to provide an in-depth understanding of a topic on which we have limited knowledge and where there is a lack of established theory. Semi-structured interviews were conducted with 14 highly-skilled and welleducated expatriate couples (amounting to 28 interviews). They were from the USA $(n=5)$, Poland $(n=5)$, Finland $(n=3)$ and Belgium $(n=1)$. Several criteria were adopted when selecting these interviews: both partners had to be working before the assignment, and to have expatriated as a couple, and then returned home. It was not a requirement that both partners worked while on assignment, as it is not always possible, and removing couples where one partner did not work from the sample could introduce a bias to our results. We also controlled for the fact that both partners were well-educated and had a professional career, and that each partner met the criteria of being engaged in continual professional employment (Bradbury, 1994) and being psychologically committed to their work and career (Harvey, 1997).

The demanding sample selection criteria meant three sources of potential candidates were used to generate the sample. First, the researcher team utilized its existing expatriate database from previous surveys to identify potential interviewees. Second, the team accessed networks to recruit the parents of children attending international schools. Finally, the snowball method was used to find additional couples already known to those DCCs identified previously. The final sample (see Table 1) included male $(n=8)$ and female $(n=6)$ expatriates and their dualcareer partners. All the expatriates were sent abroad by their employers and all worked in the private sector (i.e., telecommunications, electronics, FMCG, tobacco, construction, machine building and banking). The respondents thus represent a group of assigned expatriates in contrast to self-initiated expatriates who head abroad on their own initiative (Suutari et al., 2017). On average, the couples were on assignment for 2.6 years, with a minimum time of 1 year and maximum time of 3.5 years. Thus, the assignees fulfill the criteria of having an assignment lasting longer than a year.

\section{**** Insert Table 1 around here ${ }^{* * * * *}$}

The expatriate and the partner were interviewed separately, and interviews were conducted either in person or via telephone in cases where face-to-face meetings were not possible. All the interviews were recorded. Most interviews were carried out in English apart from the interviews with Polish repatriates, which were conducted in Polish and translated into English. 
An interview guide was prepared, and checked with two senior researchers and one human resource specialist for validity (Bryman \& Bell, 2003) before the guide was piloted with the first few couples. As a result of this process, the guide was refined and subsequently used for all interviews. Each interview was based on the same guide to cover a comparable range of topics. At the same time, issues that were particularly relevant to a respondent were sometimes discussed more extensively to allow interesting new lines of discovery to emerge and to foster unbroken discussion. The interviews lasted between 27 and 82 minutes. All recordings were transcribed, resulting in an extensive database of verbatim interview transcripts. All transcripts and recordings were stored in a database for future use and to maintain a chain of evidence.

The interview data were content analyzed using replication logic (Silverman, 2013). In a first step, all available material was reviewed with the aim of identifying the main categories emerging (e.g., repatriation adjustment issues or factors explaining the successful repatriation adjustment) and to generate a first coding frame, utilizing the concept-driven (deductive) way, combined with the data-driven (inductive) approach (Eriksson \& Kovalainen, 2015). At this stage, MaxQDA software was used to arrange and code the interview transcripts (Flick, 2014). The coding frame was subsequently refined to group the findings and respondents' quotes into key categories. Coding helped the researchers understand the key themes emerging in the data, to index the findings, and to discover and formulate new levels of interpretation. Following the coding, the full transcript material was reviewed carefully and independently by the two researchers to find both supportive and contrary evidence. After these reviews, the researchers discussed the findings and collaborated on a final version of the paper to ensure its conclusions were valid, to maximize the internal and external replicability of findings, and to achieve theoretical generalization based on deep qualitative evidence.

\section{Findings}

The goals of this research were first, to analyze the repatriation adjustment experiences and related adjustment problems of dual-career couples and, second, to identify factors identified as connected with the surprisingly positive experiences among international DCCs.

On the whole, the interviewees informing the present study reported positive repatriation adjustment experiences. In most DCC cases, repatriation expectations were met and the adjustment was found to be a very smooth process for both the assigned expatriates and their dual-career partners. Ten couples could clearly be grouped as couples with a shared view that repatriation was an easy process. Such repatriated couples reported in the following manner: 
"We were so charged with positive energy that coming back was really hassle-free" (a Polish repatriate returning from Ireland); "Coming back was great for me...I was happy to be back, to be able to work things out the way I had planned...I had a whole plan. And so far, all so good" (the partner)

"I can truly say that the whole process of coming back was really easy for us...I am really happy to be back (an American female repatriate returning from Finland); "The repatriation was an easy and in fact a really nice process for us" (the partner)

"The repatriation was not really stressful. It was the opposite. It was completely revealing...we knew what to expect on our way back” (An American repatriate returning from Finland); "Our return home was very easy. Everything was arranged well and we landed back in our old environment, friends, and family. The kids were at the perfect age to start new schools" (the partner)

Despite the emerging positive view of repatriation, some challenges did also emerge. Four of our couples reported more negative experiences, although in these cases it was typical that only one of the partners had some issues. Reflecting the importance of jobs and careers among dualcareer couples, some repatriates faced challenges at work. There were a few cases in which the careers of repatriates seem to have stagnated during the time they were on assignment, and as a result they felt of the out of sight, out of mind effect. This is how a few repatriates with some adjustment problems described their experiences:

"The international assignment has not influenced my career too much because when you come back you feel like a small fish dropped in a big ocean. People didn't see you around for a few years, so they basically forgot you" (Belgian male repatriate returning from Russia)

Two repatriates also reported the typical differences in job roles on assignment and after repatriation:

"When you go back to your working life in your home country...then comes the frustration part because you no longer have the freedom at work and you go back to the bigger structure (with less autonomy)" (Belgian male repatriate returning from Russia)

"Well, I came back to the company to the same position and that was a challenge as I felt no progress..." (Polish male repatriate returning from Finland) 
The fact that a DCC comprises two career-oriented individuals creates a situation in which two partners have to adjust to changes to working life on repatriation. Work-related adjustment challenges appeared in a few cases among partners who had not been working abroad, although the most common situation was that they had an option of returning to their old jobs. In such cases the repatriation was naturally much easier. If a new job was required, the fact that partners often had a break in their career made the search more difficult:

"I did not have a job to repatriate to... Currently I am working on my resumé in order to start looking for a job. It seems it is going to be a challenge...I lost contact with the job market here. Now I have to re-build, and it seems to take some time" (a partner of an American repatriate returning from Finland)

The typical difference between expatriates and partners was that the expatriate continued his/ her career and had new international work experience to add to their CV. Partners, by contrast, have often had a break in their careers while abroad due to a lack of knowledge of the local language, lack of a work permit, or owing to an inability to continue in their profession because of different regulations in the host country, or for family reasons. Where they did work, they were not able to have equally high-status jobs. Hence, these respondents did not have such optimistic expectations for career progression after the period abroad as their (working expatriate) partners did. Their main expectation was to get back to the career they had before the assignment. A shared experience was that one partner had prioritized the career of the other for a few years (even though they too wanted the international life experiences for themselves and their family). These partners had been ready to facilitate the career development opportunities of their working partners even if the impact on themselves was not entirely positive. In such cases the family took decisions on expatriation and on repatriation together:

"For him staying longer...would have required him to either leave the job or somehow to organize it so that he could work from Munich...that was one of the main reasons that we came back...It was a decision of the whole family" (a Finnish female repatriate returning from Germany).

The literature notes that both repatriates and their partners must deal with significant cultural change while on assignment, and come back to their home country as changed individuals (Suutari \& Välimaa, 2002; Kraimer et al., 2012). The interviewees thus inevitably faced a few social issues. The native country, when seen through the new perspective acquired while on 
assignment, can lose its attractiveness and some cultural aspects were critically re-evaluated in the light of new experiences. Rebuilding social connections at home also takes some time:

"Finland is really a very closed society and it is not all that positive...Finally, you get used to that again but there is the whole process that you have to go through and adapt yourself to this new environment" (Finnish male repatriate returning from China)

"You have not seen these people for few years so it takes some time to re-establish your credibility, get to know them again, and to re-form connections" (Belgian repatriate returning from Russia).

Similarly, a few DCCs reported concerns with the integration of children back into domestic schools; although most saw no problems. One solution was to have the children continue in international schools:

“There was only a problem with my daughter's school. Kids bond with the place and it was a bit painful for my daughter to change school. After few months in public school we ended by changing to an international school" (partner of a Polish repatriate returning from Finland)

While some adjustment challenges were reported in some cases, in the main, the view emerging of the repatriation adjustment of DCCs was far more positive than expected. The following section discusses the factors that may have facilitated this positive repatriation experience.

\section{Reasons behind Successful Repatriation Adjustment Experiences}

The overall positive nature of repatriation seemed to be connected with the nature of the DCCs' experiences. Four main factors that facilitated adjustment to repatriation were identified: active self-management of the expatriation process, earlier experience of expatriation and repatriation, successful integration of work and family life, and the realization of dual-career interests upon repatriation. We discuss each in turn.

\section{Active self-management of the expatriation process}

Our dual-career couples often reported meticulously planning their expatriation and repatriation processes, and their careers as a whole. They had often negotiated shorter term assignments than were suggested by the company, declined to extend their stay abroad, or had not accepted earlier proposals that did not suit their DCC situation. The locations and timing of assignments were analyzed from the perspective of both partners' careers. In some cases, 
partners followed the expatriate later on when the timing suited their own career arrangements. When return happens after a predefined and relatively short time, it is not only easier for the repatriates, but it also helps to maintain a tighter link with the organization. This helps when making repatriation arrangements. The respondents described their planning orientation before leaving on assignment as follows:

"In a way, there are more problems to be solved when both of the people have careers. You need to think really deeply about your life and future, and consider how such decisions influence the many aspects of your life as a couple" (a male partner of a Polish repatriate returning from Switzerland).

"Overall, Ineed to say that the whole process of deciding to leave was very well thought through" (a Polish partner of a repatriate returning from Ireland)

The relocation was typically undertaken at a time that suited the plans of both partners and the assignment was kept within the agreed timeframe, even in the apparently frequent cases when employers offered extensions. The successful repatriation experience of dual-career couples, may in fact be partly pre-programmed from the beginning of the assignment if there is good planning in place. Furthermore, and partly as a result, most of the observed dual-career expatriations were relatively short, between one and three years, and this fact eased repatriation too. In some cases, the partner repatriated around six months before the expatriate to meet requirements relating to maintaining their career progress at home. Since DCCs need to integrate two careers, the opinions of both partners matter when the time comes to decide on repatriation. This additional demand to thoroughly discuss, align, and plan available options might lead to greater accountability for decisions, which was found to help with repatriation adjustment:

"For me it was always very clear that I have a timeline during the assignment so it was always two or three years... This gives me a positive pressure to carefully plan and direct my career...In China, two years were a clear choice because my wife wanted to go back to work" (Finnish male repatriate returning from China).

\section{Earlier experience of expatriation and repatriation}

It was very common for both partners of DCCs in our sample to be very internationally experienced. Their international orientation boosts the motivation and interest in making a move abroad and eases adjustment when there. Their early international orientation had often led the respondents to study or work abroad previously, and the respondents viewed the 
experience positively. Such experiences in turn lead to having more realistic expectations about life abroad in general, and about the demands and consequences of an international assignment specifically:

"I was an exchange student when I was like 17. I did one year in the USA and thereafter I had summer jobs in Sweden and in Germany, and then I went to study in Columbia University [in the USA]...I got married and we lived in Finland..." (Finnish female repatriate returning from Germany)

"Straight after my studies I had a short six-month-long assignment in Holland and I loved it. I wanted to provide the same experience for my wife and therefore when the opportunity came I was really enthusiastic about it." (a partner of a Polish repatriate returning from Switzerland)

These earlier experiences were remembered very positively as helping develop language skills, cross-cultural competences, and self-confidence. Prior experience naturally eased decision making on future expatriation, and was seen to be very helpful on new rounds, both when going abroad and on repatriation:

"Expectations were more positive as we went for the second international assignment as a family. There was no fear of culture shock, no concerns about the kids going to school and those kind of worries. This was the positive enthusiasm that made it easier ... On repatriation, it was my second time now, so I know what awaits me" (Finnish male repatriate returning from China)

"I knew what to expect because I had been in Sweden before. Therefore, I knew what to expect, and so did my partner" (Polish repatriate returning from Finland)

The international orientation was also reflected in the couples wanting to offer their children or partner the opportunity to have an international experience. Its importance was emphasized by almost all DCCs with children:

"We looked at our children and wanted to give them a bit more of a global perspective. To give them a chance to see the world" (American repatriate returning from Finland). Afterwards, the partners were usually very satisfied with the international experience of the whole family. Such positive orientations toward internationalization, earlier international experiences, and new positive experiences naturally helped the individuals and their family members with the repatriation process. 


\section{Successful integration of work and family life}

For DCCs, family issues demand careful consideration in terms of the career plans of both partners, especially female partners, since having children automatically involves at least a short career break for them. In addition, the need to devote more family time to raising children challenges the work-life balance of two career-oriented people, who might often work long hours or travel extensively for work. In our sample of international DCCs, it was common that the period of living abroad was planned to take account of the growth of the family. Families handled this either by postponing plans to move abroad or by adjusting the timing of having children. Owing to a new family situation, the career concerns of the female partner were less problematic than they might have been before children were involved, and the couple was able to maximize the benefits of the situation by focusing on family issues during expatriation.

"Going abroad we had plans to start a family... When having children, at least in the beginning, a woman is out of an active career anyway. The fact that during the first year our son was born, and the twins later, were all connected to our plan. Later there was a question of her professional career and how to continue that" (a Polish repatriate returning from Finland)

Since expatriation is a temporary situation, repatriation offers the opportunity to plan daily family life again with a longer-term perspective. Repatriates often saw that the new situation made it possible for them to start positive and engaging family projects such as building a new house or a summer cabin. As described above, many families had utilized the period abroad to have children and so this changed the family situation and new housing arrangements were needed. Such family affairs were facilitated through the savings accumulated abroad, by one partner having a higher-status job with the increased earnings than before, or perhaps by the fact that both dual-career partners started to earn again:

"People had told us that when you came back you may get bored. It was one of the reasons we decided to start building a new house ... so we decided to have a big project that doesn't allow us to get bored" (American repatriate returning from Romania)

The months immediately after repatriation were thus filled with the realization of new possibilities and dreams that were not possible before the assignment or during it. These additional tasks, undertaken on top of already busy DCC schedules, further reduced opportunities to dwell on potential difficulties. This contrasts sharply with the situation of single-career expatriation, when the non-working, trailing partner is engaged full time in 
organizing family and social life in the new place, having more time to notice and contemplate the difficulties of repatriation. Among our sample, almost all previously non-working expatriate partners returned to work quickly when they got home, there was no time to think about problems. This supported the overall positive impression of the repatriation process.

\section{Realization of dual-career interests upon repatriation}

Owing to the dual-career orientation of the family, it was very common for repatriation to be seen as a well-anticipated, positive situation, which made it possible once again for both partners to have a career. Job-related factors were therefore high on the agenda set for discussions on possible repatriation. Quite often there were also opportunities for continuing the stay abroad, but the decision to repatriate was made mainly due to the career interests of the non-assigned partner, for whom repatriation represented an opportunity to recommence their career. Accordingly, repatriation was generally seen as something positive for most DCCs, which overshadowed any difficulties. Naturally, this was important in particular for a partner, but also affected the shared experience of both partners. For example, expatriates were often aware that their partners were making a sacrifice in abandoning their career when moving abroad. In that sense, it was a relief to both partners to get back to life as it used to be as a dualcareer couple.

"Living abroad was nice but personally I need to have a job...There are very clear ladders in my profession, lots of specialization and related exams. If you are out of it, you are losing everything...I wanted to repatriate to go back to my job. I missed my work a lot" (Belgian partner of repatriate returning from Russia)

"It was difficult for her (to leave her job) because she was in a good place at work, but I think that as a couple it wasn't that hard because it was such a good career opportunity for me...the decision to come back was actually a relief" (American repatriate returning from Finland)

In a few cases, the partners' careers progressed soon after repatriation, though typically such an outcome involved a change of employer. The international perspective and increased feeling of self-confidence helps dual-career partners embark on new challenges, and encourages the search for new, more, and more rewarding jobs. Sometimes they received new job offers:

"The repatriation process was really easy from my perspective. After coming back home, I have started to work. I still had my position in the old company, but I got an 
offer from a different company and accepted that. Now I work as a director in an ITcompany. For me it was easy to get a new job" (Finnish female partner returning from China)

If the expatriate's partner has strong professional skills, they might have the option of selfemployment, either before the assignment or during the expatriation, which can offer the partner a route to maintaining the engagement with his or her career while abroad. If the company was set up in the home country and work was organized at a distance, repatriation offered better opportunities for developing the business and thus added a positive motivation to the repatriation process.

"I am an architect / designer and I used to work for a construction company...I wanted to be more independent so I decided one day to open my own company...I opened my company when we were abroad... and that continued after the return" (Polish female partner of repatriate returning from Finland)

For our assigned expatriates, repatriation made it possible to continue their careers back home, and consequently their assessment of their career situation was largely positive:

"This definitely progressed my career...I was basically requested to come back to the USA to take over a division. That was a big promotion for me and so coming back was a very positive experience"(American repatriate returning from Japan)

"It gave a certain boost when I got a promotion when I came back to Finland" (Finnish female repatriate returning from Germany).

When career concerns are central to DCCs, career success after the assignment reinforces the positive nature of the overall experience, supporting the view of the DCC partners that the effort connected with moving abroad were worthwhile, which in turn helps manage the adjustment to repatriation. Future career progress was one goal, if not the main one, for living abroad.

\section{Discussion and conclusions}

The present study aimed to improve our understanding of the largely neglected angle of dualcareer couple repatriation. The findings indicated that the clear majority of respondents and couples reported a very smooth repatriation process. Our findings among dual-career couples thus clearly contrast with previous repatriation research, which builds a view of repatriation as 
a very challenging experience for repatriates (Kraimer et al., 2012; Haslberger et al., 2012, Storti, 2003, Mäkelä \& Suutari, 2013). Furthermore, it has previously been suggested (e.g., Haslberger et al., 2012; Linehan \& Scullion, 2002; Kierner, 2015) that DCCs can struggle with repatriation challenges even more than single-career expatriates. We however found mainly positive experiences, and the few identified repatriation challenges were in line with earlier findings on repatriation (Szkudlarek, 2010; Kraimer et al., 2012, Sanchez-Vidal et al., 2008; Suutari \& Välimaa 2002). Among career-oriented DCCs, it not surprising that some challenges appeared with regard to their work adjustment.

The main contribution of this paper therefore relates to the unexpected positive repatriation experiences of the partners in DCCs, and in particular to the reasons for such positive experiences. Contrary to expectations, the specific features of a DCC seem to facilitate a smooth repatriation process. Four main themes explaining the positive nature of repatriation adjustment of international DCCs were identified in the present study.

The first factor identified as facilitating successful repatriation of international DCCs concerns their active self-management of the expatriation process. The need for individuals to manage their own career has been emphasized in career theory in line with the increasingly boundary less nature of careers (Andresen et al., 2015). An outcome of professionals' protean career attitudes (see e.g., Shaffer et al.2012) is that individuals take responsibility for the management of their careers. The role of such attitudes and career-management activities is particularly important in the international career context. Our findings are that career-management activities seem to be very common among DCCs.

However, the reasons for such activity were mainly discussed in connection with the requirements for DCCs to plan their career moves in parallel, taking into account the similar concerns of their partner (Känsälä et al., 2015). It therefore seems that such career-management activities are not so much linked with individual level protean attitudes as with the realities created by the dual-career situation. The existing research indicates that couples integrate their career interests through a range of career coordination strategies (Solga \& Rusconi, 2007). In a hierarchical career strategy, one career is prioritized over the other in decision making (Baird $\&$ Reeves, 2011). Doing so might involve prioritizing the family aspect through the partners reducing or abandoning paid work, and abandoning their career path, at least temporarily. Alternatively, the partners might adopt an egalitarian strategy in which the careers of both partners are considered equally important (Solga \& Rusconi, 2007). In the current research, the 
use of the hierarchical strategy was dominant. By accepting international mobility, the partners often have to accept the fact that it is beneficial for the career of one partner, but not for the other. In cases where expatriation was planned in such a way as to facilitate the working lives of both partners, a more egalitarian approach was evident. In line with the findings of Känsälä et al. (2015), some couples changed their coordination strategies during the process, that is, a couple initially prioritizing the expatriate's career might later prioritize the career of the partner when making decisions on repatriation.

The second main theme emerging from the interviews was connected with the earlier experience of the highly educated professional dual-career couples on expatriation and repatriation in the present sample. Such international experience reflects their international orientation (Suutari \& Taka, 2004; Cerdin \& Pargneux, 2010) which has been found to be common among experienced expatriates. For some, it has been an important aspect in their orientation from the early stages of their education and career, while among others it has developed through their first international experiences being positive, which has heightened the interest in an international career in the longer term (Suutari, 2003). We found that owing to their orientation, the DCCs also saw it as important that their children have such experiences. In particular, such an orientation meant that one or both partners had previous international experience and felt that they could clearly benefit from that during repatriation. This experience thus clearly facilitated a smooth repatriation process.

The third main factor concerned the successful integration of the work and family lives of international DCCs (Rusconi et al., 2013). We found that the planning of expatriation was often closely combined with family planning, which meant partners did not necessarily have additional breaks in their careers. This also affected their repatriation experiences when, for example, Finnish mothers have a legal right to stay on paid parental leave for nine months and then a further legal right to continue family leave for around two years and still keep their jobs. Accordingly, all the couples based in Finland who had very young children during the assignment could keep their jobs waiting for them, making repatriation far easier. The new family situation, in combination with an often-improved financial situation, presented new positive opportunities for these DCCs to plan their new family life on repatriation.

The final factor contributing to the successful repatriation of DCCs was the realization dualcareer interests upon repatriation. The discussion around the career impact of expatriation is often built on human capital theory, which predicts that developmental job experiences provide 
valuable learning that should have a positive impact on employees' long-term careers within and/ or beyond their organizations (Kraimer et al., 2009). In the light of that theory, expatriation could be expected to have a positive impact on the careers of repatriates. However, there is a great deal of discussion in the literature over whether the theory holds true for expatriates, who can face problems getting back into the job market in their home countries. Because most multinational corporations do not have clear career-path strategies for repatriates, the anticipated career progress may not happen (Andreason \& Kinneer, 2005). The research evidence is mixed, and most studies among repatriates have been carried out fairly soon after repatriation, and thus longer-term career impacts may be more positive than reported (Suutari et al., 2017). In the present study, it appeared that among expatriate DCCs, repatriation was usually a positive experience. When expatriates found challenging and interesting jobs after the repatriation, it had a great impact on their overall adjustment to repatriation. This was particularly so among the kind of career-driven business professionals for whom developmental and career-related motivations were important factors influencing the original decision to go abroad. Overall, the employee taking up a suitable job after repatriation is the main determinant of the repatriate's satisfaction, and a key factor in their turnover intention (Sanchez-Vidal et al., 2007; Lazarova \& Cerdin, 2007). For example, $86 \%$ of the variance in overall satisfaction with repatriation was accounted for by a single item measuring the impact of the assignment on the subjects' career (Gomez-Mejia \& Balkin, 1987). The experiences of partners were at least as positive, although for slightly different reasons. The partners were keen to get back to their jobs and careers, and had thus overcome commonly shared frustrations and a feeling of stalled career progress often felt during an assignment (Kraimer at al., 2012). Accordingly, the generally shared view among our DCCs was that repatriation was a positive experience that went smoothly.

Our study does also have some limitations that should be borne in mind when interpreting the findings. This is a qualitative study with a limited number of international DCCs, thus future research with larger samples would help to validate the findings. Our sample was cross-cultural but still dominated by European couples; thus, more evidence would be needed from other institutional contexts to establish whether there are important cross-cultural differences in the situations of DCCs across countries. The presence of children may have a more convoluted impact on repatriation experiences than described in the paper. Future research could establish in more detail the effect of the presence and age of children on the repatriation of DCCs in both 
the short and long term. It may be possible that children initially inhibit satisfaction due to school adjustment challenges, but later improve it as the benefits of acquiring broader perspectives and language skills become apparent as they continue their education in their home country, until finally that effect fades with time. Our sample primarily constituted couples with children, interviewed within one year of return, hence such longer-term effects could not be observed. The other relevant contingency factors may include length of assignment and the spouse's job situation during the expatriation assignment. In particular, it could be expected that if the spouse has a fully satisfying job during the international assignment, the positive effects of returning to a career upon repatriation may be diminished. Such situations are however rare, at least in our sample, and thus we could not analyze this further. Overall, in order to be able to fully analyze the impact of such contingency factors, a larger sample would be needed. Finally, the expatriates in our sample of highly-educated DCCs typically worked at the higher levels of their organizations (e.g., as managers or directors) and thus the findings might be have differed if we had interviewed different people, such as younger couples in the early stages of their careers; however, young people with less experience are rarely sent abroad by their employers.

\section{References}

Andreason, A. W. (2008). Expatriate adjustment of spouses and expatriate managers: An integrative research review. International Journal of Management, 25(2), 382-395.

Andreason, A. W., \& Kinneer, K. D. (2005). Repatriation adjustment problems and the successful reintegration of expatriates and their families. Journal of Behavioral and Applied Management, 6(2), 109-126.

Andresen, M., Biemann, T., \& Pattie, M. W. (2015). What makes them move abroad? Reviewing and exploring differences between self-initiated and assigned expatriation. The International Journal of Human Resource Management, 26(7), 932-947. https://doi.org/10.1080/09585192.2012.669780

Baird, M., \& Reeves, K. (2011). "Breaking the Roles": Female Breadwinner Families. $4^{\text {th }}$ International Community, Work and Family Conference, 19-21 May, Tampere, Finland. 
Benson, G. S., \& Pattie, M. (2008). Is expatriation good for my career? The impact of expatriate assignments on perceived and actual career outcomes. The International Journal of Human Resource Management, 19(9), 1636-1653.

https://doi.org/10.1080/09585190802295058

Bird, G., \& Schnurman-Crook, A. (2005). Professional identity and coping behaviors in dualcareer couples. Family Relations, 54(1), 145-160. https://doi.org/10.1111/j.01976664.2005.00012.x

Black, J. S., \& Stephens, G. K. (1989). The influence of the spouse on American expatriate adjustment and intent to stay in Pacific Rim overseas assignments. Journal of management, 15(4), 529-544. https://doi.org/10.1177/014920638901500403

Black, J. S., Gregersen, H. B., \& Mendenhall, M. E. (1992). Toward a theoretical framework of repatriation adjustment. Journal of International Business Studies, 23(4), 737-760. https://doi.org/10.1057/palgrave.jibs.8490286

Bonache, J. (2005). Job satisfaction among expatriates, repatriates and domestic employees: The perceived impact of international assignments on work-related variables. Personnel review, 34(1), 110-124. https://doi.org/10.1108/00483480510571905

Bradbury, S. L. (1994). Dual career couples in R\&D labs. Research-Technology Management, 37(1), 45-48.

Brammer, L. M., \& Abrego, P. J. (1981). Intervention strategies for coping with transitions. The Counseling Psychologist, 9(2), 19-36. https://doi.org/10.1177/001100008100900203

Breitenmoser, A., \& Bader, B. (2016). Repatriation outcomes affecting corporate ROI: a critical review and future agenda. Management Review Quarterly, 66(3), 195-234. https://doi.org/10.1007/s11301-016-0119-6

Brookfield, G. M. A. C. (2016). Global Relocation Trends Survey Report 2013. Chicago, US: Brookfield Global Relocation Services.

Bryman, A., \& Bell, E. (2003). Synthesizing Research. A guide for Literature Reviews (3rd ed.). Thousand Oaks, CA: Sage Publications. 
Cerdin, J. L., \& Pargneux, M. L. (2010). Career anchors: A comparison between organization-assigned and self-initiated expatriates. Thunderbird International Business Review, 52(4), 287-299. https://doi.org/10.1007/s11301-016-0119-6

Chi, S. C. S., \& Chen, S. C. (2007). Perceived psychological contract fulfillment and job attitudes among repatriates: An empirical study in Taiwan. International Journal of Manpower, 28(6), 474-488. https://doi.org/10.1108/01437720710820008

Greer, T. W., \& Stiles, A. C. (2016). Using HRD to Support Repatriates: A Framework for Creating an Organization Development Strategy for Repatriation. Human Resource Development Review, 15(1), 101-122. https://doi.org/10.1177/1534484315626019

Gregersen, H. B., \& Black, J. S. (1999). The right way to manage expats. Harvard business review, 77(2), 52-59.

Eriksson, P., \& Kovalainen, A. (2015). Qualitative Methods in Business Research: A Practical Guide to Social Research. London, England: Sage Publications.

Flick, U. (2014). An introduction to qualitative research. London, England: Sage Publications.

Gomez-Mejia, L., \& Balkin, D. B. (1987). The determinants of managerial satisfaction with the expatriation and repatriation process. Journal of Management Development, 6(1), 7-17. https://doi.org/10.1108/eb051631

Haslberger, A., \& Brewster, C. (2008). The Expatriate Family - an international perspective Journal of Managerial Psychology, 23(3), 324-346.

Haslberger, A., Brewster, C., \& Hippler, T. (2014). Managing performance abroad: A new model for understanding expatriate adjustment. New York, NY: Routledge.

Handler, C. A., \& Lane, I. M. (1997). Career planning and expatriate couples. Human Resource Management Journal, 7(3), 67-78. https://doi.org/10.1111/j.17488583.1997.tb00429.x

Harvey, M., Napier, N. K., Moeller, M., \& Williams, L. A. (2010). Mentoring Global DualCareer Couples: A Social Learning Perspective. Journal of applied social psychology, 40(1), 212-240. https://doi.org/10.1111/j.1559-1816.2009.00571.x 
Harvey, M., Novicevic, M., \& Breland, J. W. (2009). Global dual-career exploration and the role of hope and curiosity during the process. Journal of Managerial Psychology, 24(2), 178197. https://doi.org/10.1108/02683940910928874

Harvey, M. (1997). Dual-Career Expatriates: Expectations, Adjustment and Satisfaction with International Relocation. Journal of International Business Studies, 28(3), 627-658.

Retrieved from http://www.jstor.org/stable/155428

Harvey, M. (1998). Dual-career couples during international relocation: The trailing spouse. International Journal of Human Resource Management, 9(2), 309-331. https://doi.org/10.1080/095851998341116

Haslberger, A., Brewster, C., \& Hippler, T. (2012). Repatriation and repatriation adjustmentindividual and organisational perspectives. The 12th European Academy of Management Proceedings.

Haslberger, A., Brewster, C., \& Hippler, T. (2013). The dimensions of expatriate adjustment. Human Resource Management, 52(3), 333-351. https://doi.org/10.1002/hrm.21531

Hechanova, R., Beehr, T. A., \& Christiansen, N. D. (2003). Antecedents and consequences of employees' adjustment to overseas assignment: a meta-analytic review. Applied Psychology, 52(2), 213-236. https://doi.org/10.1111/1464-0597.00132

Howe-Walsh, L., \& Torka, N. (2017). Repatriation and (perceived) organisational support (POS) The role of and interaction between repatriation supporters. Journal of Global Mobility: The Home of Expatriate Management Research, 5(1), 60-77. https://doi.org/10.1108/JGM-09-2016-0040

Huffman, A. H., \& Frevert, T. K. (2013). Three jobs, two employees and one family: the experiences of dual-earner couples. In D. A. Major, \& R. J. Burke (Eds.), Handbook of Work_Life Integration Among Professionals: Challenges and Opportunities, (pp. 142-160). Cheltenham, UK: Edward Elgar Publishing.

Känsälä, M., Mäkelä, L., \& Suutari, V. (2015). Career coordination strategies among dual career expatriate couples. The International Journal of Human Resource Management, 26(17), 2187-2210. https://doi.org/10.1080/09585192.2014.985327 
Kierner, A. (2015). Dual-Income and Dual-Career Couples in International Context. In L. Mäkelä, \& V. Suutari (Eds.), Work and Family Interface in the International Career Context, (pp. 95-116). Cham, Switzerland: Springer International Publishing. https://doi.org/10.1007/978-3-319-17647-5_6

Kraimer, M. L., Shaffer, M. A., \& Bolino, M. C. (2009). The influence of expatriate and repatriate experiences on career advancement and repatriate retention. Human Resource Management, 48(1), 27-47. https://doi.org/10.1002/hrm.20265

Kraimer, M. L., Shaffer, M. A., Harrison, D. A., \& Ren, H. (2012). No place like home? An identity strain perspective on repatriate turnover. Academy of Management Journal, 55(2), 399-420. https://doi.org/10.5465/amj.2009.0644

Lauring, J., \& Selmer, J. (2010). The supportive expatriate spouse: An ethnographic study of spouse involvement in expatriate careers. International business review, 19(1), 59-69. https://doi.org/10.1016/j.ibusrev.2009.09.006

Lazarova, M. B., \& Cerdin, J. L. (2007). Revisiting repatriation concerns: Organizational support versus career and contextual influences. Journal of International Business Studies, 38(3), 404-429. https://doi.org/10.1057/palgrave.jibs.8400273

Linehan, M., \& Scullion, H. (2002). Repatriation of European female corporate executives: an empirical study. International Journal of Human Resource Management, 13(2), 254-267. https://doi.org/10.1080/09585190110102369

MacDonald, S., \& Arthur, N. (2005). Connecting career management to repatriation adjustment. Career Development International, 10(2), 145-159. https://doi.org/10.1108/13620430510588338

Mäkelä, L., Känsälä, M., \& Suutari, V. (2011). The roles of expatriates' spouses among dual career couples. Cross Cultural Management: An International Journal, 18(2), 185-197. https://doi.org/10.1108/13527601111126012

Mäkelä, L., \& Suutari, V. (2013). The work-life interface of self-initiated expatriates: conflicts and enrichment. In A. Haslberger, \& V. Vaiman, (Eds), Talent management of selfinitiated expatriates (pp. 278-303). Hampshire, UK: Palgrave Macmillan. https://doi.org/10.1057/9780230392809 
McNulty, Y., \& Moeller, M. (in press). A typology of dual-career expatriate (trailing) spouses: The 'R' profiles. In M. Dickmann, V. Suutari, \& O. Wurtz (Eds.), The Management of Global Careers: Exploring the Rise of International Work. Hampshire, UK: Palgrave Macmillan.

Olds, D., \& Howe-Walsh, L. (2014). Why repatriates resign: interviews with those who left. International Journal of Academic Research in Management, 3(1), 11-30. https://ssrn.com/abstract $=2372608$

Rapoport, R., \& Rapoport, R. N. (1971). Further considerations on the dual-career family. Human Relations, 24(6), 519-533. https://doi.org/10.1177/001872677102400607

Ravasi, C., Salamin, X., \& Davoine, E. (2013). The challenge of dual career expatriate management in a specific host national environment: An exploratory study of expatriate and spouse adjustment in Switzerland based MNCs. Working Papers SES: 447, Université de Fribourg, 1-38. http://doc.rero.ch/record/208749

Riusala, K., \& Suutari, V. (2000). Expatriation and careers: Perspectives of expatriates and spouses. Career Development International, 5(2), 81-90.

https://doi.org/10.1108/13620430010318945

Rusconi, A., Moen, P., \& Kaduk, A. (2013). Career priorities and pathways across the (gendered) life course. In D. A. Major, \& R. Burke (Eds.), Handbook of work-life integration among professionals: Challenges and opportunities, (pp. 95-119). Cheltenham, UK: Edward Elgar Publishing

Santos, G. G., \& Cabral-Cardoso, C. (2008). Work-family culture in academia: a gendered view of work-family conflict and coping strategies. Gender in Management: An International Journal, 23(6), 442-457. https://doi.org/10.1108/17542410810897553

Sanchez-Vidal, M. E., Sanz Valle, R., \& Barba Aragón, M. I. (2008). International workers' satisfaction with the repatriation process. The International Journal of Human Resource Management, 19(9), 1683-1702. https://doi.org/10.1080/09585190802295256

Sanchez-Vidal, M. E., Sanz Valle, R., Barba Aragón, M. I., \& Brewster, C. (2007). Repatriation adjustment process of business employees: Evidence from Spanish workers. International Journal of Intercultural Relations, 31(3), 317-337. https://doi.org/10.1016/j.ijintrel.2006.07.004 
Selmer, J., \& Leung, A. S. (2003). Provision and adequacy of corporate support to male expatriate spouses: An exploratory study. Personnel Review, 32(1), 9-21.

https://doi.org/10.1108/00483480310454691

Shaffer, M. A., \& Harrison, D. A. (2001). Forgotten partners of international assignments: development and test of a model of spouse adjustment. Journal of Applied Psychology, 86(2), 238-254. https://doi.org/10.1037/0021-9010.86.2.238

Shaffer, M. A., Kraimer, M. L., Chen, Y. P., \& Bolino, M. C. (2012). Choices, challenges, and career consequences of global work experiences: A review and future agenda. Journal of Management, 38(4), 1282-1327. https://doi.org/10.1177/0149206312441834

Silverman, D. (2013). Doing qualitative research: A practical handbook ( $4^{\text {th }}$ ed.). London, England: SAGE Publications.

Solga, H., \& Rusconi, A. (2007). Determinants of and obstacles to dual careers in Germany. Zeitschrift für Familienforschung, 19(3), 311-336. http://nbnresolving.de/urn:nbn:de:0168-ssoar-58150.

Storti, C. (2003). The art of coming home. Boston, MA: Intercultural Press.

Sussman, N. M. (2002). Testing the cultural identity model of the cultural transition cycle: Sojourners return home. International Journal of Intercultural Relations, 26(4), 391-408. https://doi.org/10.1016/S0147-1767(02)00013-5

Suutari, V. (2003). Global managers: career orientation, career tracks, life-style implications and career commitment. Journal of Managerial Psychology, 18(3), 185-207. https://doi.org/10.1108/02683940310465225

Suutari, V., \& Brewster, C. (2003). Repatriation: Empirical evidence from a longitudinal study of careers and expectations among Finnish expatriates. International Journal of Human Resource Management, 14(7), 1132-1151. https://doi.org/10.1080/0958519032000114200

Suutari, V., Brewster, C., Dickmann, M., Mäkelä, L. \& C. Tornikoski (2017). The effect of international work experience on the career success of expatriates: a comparison of assigned and self-initiated expatriates. Human Resource Management.

https://doi.org/10.1002/hrm.21827

Suutari, V., \& Taka, M. (2004). Career anchors of managers with global careers. Journal of Management Development, 23(9), 833-847. https://doi.org/10.1108/02621710410558440 
Suutari, V., \& Välimaa, K. (2002). Antecedents of repatriation adjustment: New evidence from Finnish repatriates. International Journal of Manpower, 23(7), 617-634.

https://doi.org/10.1108/01437720210450798

Szkudlarek, B. (2010). Reentry-A review of the literature. International Journal of Intercultural Relations, 34(1), 1-21. https://doi.org/10.1016/j.ijintrel.2009.06.006

Szkudlarek, B., \& Sumpter, D. M. (2015). What, when, and with whom? Investigating expatriate reentry training with a proximal approach. Human Resource Management, 54(6), 1037-1057. https://doi.org/10.1002/hrm.21647

Takeuchi, R. (2010). A critical review of expatriate adjustment research through a multiple stakeholder view: Progress, emerging trends, and prospects. Journal of Management, 36(4), 1040-1064. https://doi.org/10.1177/0149206309349308

Tahir, R., \& Azhar, N. (2013). The adjustment process of female repatriate managers in Australian and New Zealand (ANZ) companies. Global Business Review, 14(1), 155-167. https://doi.org/10.1177/0972150912466469

Tharenou, P. (2008). Disruptive decisions to leave home: Gender and family differences in expatriation choices. Organizational Behavior and Human Decision Processes, 105(2), 183200. https://doi.org/10.1016/j.obhdp.2007.08.004

Vance, C. M., \& McNulty, Y. (2014). Why and how women and men acquire global career experience: A study of American expatriates in Europe. International Studies of Management \& Organization, 44(2), 34-54. https://doi.org/10.2753/IMO0020-8825440202

Van Steenbergen, E. F., Ellemers, N., \& Mooijaart, A. (2007). How work and family can facilitate each other: distinct types of work-family facilitation and outcomes for women and men. Journal of occupational health psychology, 12(3), 279-300.

https://doi.org/10.1037/1076-8998.12.3.279

Webber, G., \& Williams, C. (2008). Mothers in "good" and "bad" part-time jobs: Different problems, same results. Gender \& Society, 22(6), 752-777.

https://doi.org/10.1177/0891243208325698 
Table 1. Sample Details

\begin{tabular}{|c|c|c|c|c|c|c|c|c|c|c|c|}
\hline \multicolumn{3}{|c|}{$\begin{array}{c}\text { Assignment } \\
\text { characteristics }\end{array}$} & \multicolumn{3}{|c|}{ Primary Expatriate } & \multicolumn{6}{|c|}{ Dual Career Partner } \\
\hline $\mathbf{N r}$ & $\begin{array}{c}\text { Host } \\
\text { country }\end{array}$ & Length & Nationality & Gender & $\begin{array}{c}\text { Position on the } \\
\text { assignment }\end{array}$ & Nationality & Gender & $\begin{array}{c}\text { Partner } \\
\text { profession }\end{array}$ & $\begin{array}{c}\begin{array}{c}\text { Worked } \\
\text { before the } \\
\text { expatriation }\end{array} \\
\end{array}$ & \begin{tabular}{|c|c|c}
$\begin{array}{c}\text { Worked } \\
\text { during the } \\
\text { expatriation }\end{array}$ \\
\end{tabular} & $\begin{array}{c}\begin{array}{c}\text { Worked after } \\
\text { the } \\
\text { repatriation }\end{array} \\
\end{array}$ \\
\hline 1 & Romania & 3 & American & Female & Associate Director & Polish & Female & $\begin{array}{l}\text { Project Portfolio } \\
\text { Leader }\end{array}$ & Yes & Yes & Yes \\
\hline 2 & Ireland & 3 & Polish & Male & Network Engineer & Polish & Male & Psychologist & Yes & No & Yes \\
\hline 3 & Germany & 3 & Finnish & Female & $\begin{array}{c}\text { Senior Legal } \\
\text { Counsel }\end{array}$ & Finnish & Female & Pilot & Yes & Yes & Yes \\
\hline 4 & Finland & 3 & Polish & Male & Regional Director & Polish & Male & $\begin{array}{c}\text { Property broker - } \\
\text { company owner }\end{array}$ & Yes & Yes, remotely & Yes \\
\hline 5 & Finland & 3 & American & Female & $\begin{array}{c}\text { Communication } \\
\text { Manager }\end{array}$ & American & Female & $\begin{array}{c}\text { Partner } \\
\text { Investment } \\
\text { Consulting } \\
\end{array}$ & Yes & $\begin{array}{l}\text { Yes, at the } \\
\text { final stage }\end{array}$ & Yes \\
\hline 6 & China & 2 & Finnish & Female & HR Director & Finnish & Female & $\begin{array}{c}\text { IT } \\
\text { Project Manager }\end{array}$ & Yes & No & Yes \\
\hline 7 & Japan & 2 & American & Male & $\begin{array}{c}\text { VP of Marketing and } \\
\text { Sales }\end{array}$ & American & Male & English Teacher & Yes & Yes, Part time & Yes \\
\hline 8 & Finland & 3 & Polish & Male & $\begin{array}{c}\text { Project Manager / } \\
\text { Dev Leader }\end{array}$ & Polish & Male & $\begin{array}{l}\text { Architect } \\
\text { Designer }\end{array}$ & Yes & $\begin{array}{c}\text { Yes, } \\
\text { Remotely }\end{array}$ & Yes \\
\hline 9 & France & 2 & Polish & Male & $\begin{array}{c}\text { Head of Foreign } \\
\text { Exchange }\end{array}$ & Polish & Male & Librarian & Yes & No & Yes \\
\hline 10 & Finland & 3 & American & Female & $\begin{array}{c}\text { VP of } \\
\text { Communication } \\
\end{array}$ & American & Female & Sales Manager & Yes & No & Yes \\
\hline 11 & Switzerland & 1 & Polish & Female & Marketing Director & Polish & Female & $\begin{array}{c}\text { IT } \\
\text { Project Manager }\end{array}$ & Yes & No & Yes \\
\hline 12 & Finland & 3.5 & American & Male & $\begin{array}{c}\text { Sr. Global Financial } \\
\text { Manager }\end{array}$ & American & Male & $\begin{array}{l}\text { Logistics } \\
\text { Manager }\end{array}$ & Yes & No & $\begin{array}{l}\text { Looking for a } \\
\text { job at the time } \\
\text { of the interview }\end{array}$ \\
\hline 13 & Russia & 3,5 & Belgium & Male & Operation Director & Belgium & Male & Nurse & Yes & $\begin{array}{c}\begin{array}{c}\text { Yes, part time } \\
\text { at the final } \\
\text { stage }\end{array} \\
\end{array}$ & Yes \\
\hline 14 & China & 2 & Finnish & Male & Logistics Director & Finnish & Male & Project Manager & Yes & No & Yes \\
\hline
\end{tabular}

